\title{
PERAN GURU PAI DALAM MENINGKATKAN KEDISIPLINAN PESERTA DIDIK DI KELAS VII SMP PERSIAPAN TOMI - TOMI KECAMATAN WAESALA KABUPATEN SERAM BAGIAN BARAT
}

\author{
Kader Wali ${ }^{1}$ \\ Program Studi Pendidikan Agama Islam Fakultas IImu Tarbiyah dan Keguruan \\ Institut Agama Islam Negeri Ambon ${ }^{1}$ \\ Email: kaderwally@iainambon.ac.id
}

\begin{abstract}
The purpose of this study was to determine the role of PAl teachers in improving the discipline of students in the classroom VII SMP Preparation Tomi-Tomi District Waesala Seram Bagian Barat and to find out the supporting factors and factors inhibiting the role of PAI teachers in improving the discipline of learners in the classroom VII SMP Preparation Tomi-Tomi District Waesala Seram Bagian Barat. The research was conducted from March 2, 2018 to April 2, 2018, In SMP Preparation Tomi-Tomi District Waesala Seram Bagian Barat. This research approach is descriptive qualitative with data collection techniques in the form of observations and interviews. The collected data is then analyzed using the techniques presented by the Milles and Huberman, include data reduction, data presentation, and inference. The results showed that the role of PAI teachers in improving the discipline of students in the classroom VII SMP Preparation Tomi-Tomi District Waesala Seram Bagian Barat among others: provide examples of discipline for learners by coming to school on time; advising learners on discipline; reprimand and punish students who arrive late; scolding students who often (repeatedly) arrive late; and control the activities of students at school and at home. Thus, PAl teachers in this case play more role as an educator and exemplar than just being a teacher. Supporting factors and inhibition factors in the role of PAl teachers in improving the discipline of students in the classroom VII SMP Preparation Tomi-Tomi District Waesala Seram Bagian Barat, among others, the supporting factors are the application of school rules and discipline, the role of the headmaster who is quite firm on the issue of discipline both teachers and students. As for the inhibition factor is the lack of cooperation between teachers, lack of awareness of learners to be disciplined, lack of awareness of parents in paying attention to the discipline of learners when at home, there are still many teachers who give assignments individually rather than group assignments, and PAI teachers often get criticism and suggestions that do not build from the community or parents of learners.
\end{abstract}

Keywords: PAI Teacher Role, Student Discipline, SMP Preparation Tomi-Tomi

\begin{abstract}
Abstrak: Tujuan penelitian ini adalah untuk mengetahui peran guru PAl dalam meningkatkan kedisiplinan peserta didik di Kelas VII SMP Persiapan Tomi-Tomi Kecamatan Waesala Kabupaten Seram Bagian Barat dan untuk mengetahui faktor pendukung dan faktor penghambat peran guru PAI dalam meningkatkan kedisiplinan peserta didik di Kelas VII SMP Persiapan Tomi-Tomi Kecamatan Waesala Kabupaten Seram Bagian Barat. Penelitian dilaksanakan dari tanggal 02 Maret 2018 sampai dengan 02 April 2018, di SMP Persiapan Tomi-Tomi Kecamatan Waesala Kabupaten Seram Bagian Barat. Pendekatan penelitian ini merupakan deskriptif kualitatif dengan teknik pengumpulan data berupa observasi dan wawancara. Data yang terkumpul kemudian dianalisis dengan menggunakan teknik yang dikemukakan oleh Milles dan Huberman, meliputi reduksi data, penyajian data, dan penarikan kesimpulan. Hasil penelitian menunjukkan bahwa peran guru PAI dalam meningkatkan kedisiplinan peserta didik di Kelas VII SMP Persiapan Tomi-Tomi Kecamatan Waesala Kabupaten Seram Bagian
\end{abstract}


Barat antara lain: memberikan contoh (teladan) kedisiplinan bagi peserta didik yakni dengan datang ke sekolah tepat waktu; memberikan nasihat kepada peserta didik tentang kedisiplinan; menegur dan memberikan hukuman kepada peserta didik yang datang terlambat; memarahi peserta didik yang sering (berulang-ulang) datang terlambat; dan mengontrol kegiatan peserta didik di sekolah maupun di rumah. Dengan demikian, guru PAI dalam hal ini lebih berperan sebagai seorang pendidik dan pemberi teladan daripada hanya sekedar menjadi seorang pengajar. Faktor pendukung dan faktor penghambat peran guru PAI dalam meningkatkan kedisiplinan peserta didik di Kelas VII SMP Persiapan Tomi-Tomi Kecamatan Waesala Kabupaten Seram Bagian Barat, antara lain untuk faktor pendukung adalah penerapan aturan dan tata tertib sekolah, peran kepala sekolah yang cukup tegas terhadap masalah kedisiplinan baik guru maupun peserta didik. Sedangkan untuk faktor penghambatnya adalah kurang adanya kerja sama antar sesama guru, kurangnya kesadaran peserta didik untuk menjadi orang yang disiplin, kurangnya kesadaran orang tua dalam memperhatikan kedisiplinan peserta didik ketika di rumah, masih banyak guru yang memberikan tugas secara individu daripada tugas kelompok, dan guru PAl sering mendapat kritik dan saran yang tidak membangun dari masyarakat ataupun orang tua peserta didik.

Kata kunci: Peran Guru PAI, Kedisiplinan Peserta Didik, SMP Persiapan Tomi-Tomi

\section{PENDAHULUAN}

Manusia adalah makhluk yang diciptakan Tuhan paling sempurna dari pada makhluk-makhluk lainnya di muka bumi ini. Manusia memiliki akal dan berpikir untuk merenovasi hidupnya dengan membangun semua unsur terkecil sampai terbesar sekalipun dimana manusia itu memiliki kemampuan, salah satunya adalah membangun dirinya sendiri menuju manusia seutuhnya. Membangun manusia seutuhnya merupakan hakikat daripada tujuan Pembangunan Nasional, bangsa Indonesia sedang giatgiatnya membina sumber manusia yang berkualitas untuk kelangsungan kehidupan bernegara, terutama dari generasi muda sebagai penerus untuk melanjutkan dan mengisi pembangunan sehingga tercapainya masyarakat yang adil dan makmur. Oleh karena itu, pembangunan dari segi mental spiritual sangat penting dan diperlukan untuk menunjang pembangunan segi material (Abdul Majid, 2006).

Seseorang dikatakan menjalankan ketertiban jika orang tersebut menjalankan peraturan karena pengaruh dari luar misalnya guru, kepala sekolah, orang tua dan lain-lain. Kedisiplinan peserta didik diperlukan agar mempunyai sikap yang mampu mencerminkan ketaatan dan ketepatan terhadap aturan-aturan sehingga dalam proses belajar mengajar, pembelajaran dapat berjalan kondusif. Untuk mendisiplinkan berarti 
menginstruksikan orang untuk mengikuti tatanan tertentu melalui aturanaturan tertentu. Dalam arti lain, disiplin berarti suatu ilmu tertentu yang diberikan kepada murid (Syaiful Bahri Djamarah, 2000).

Disiplin menciptakan pribadi yang positif dan kontrol diri kepada suswa agar peserta didik memperoleh suatu pengetahuan yang baru. Jika diterapkan dengan benar, disiplin mencerminkan sikap yang menjadi perhatian guru, suatu keadaan kondusif yang memungkinkan peserta didik untuk berkembang. Disiplin yang efektif menuntut guru untuk mampu bertindak saat perilaku tersebut dilakukan (Singgih D Gunarso, 2000).

Dari pendapat di atas, dapat disimpulkan bahwa disiplin merupakan suatu tindakan latihan watak dan batin yang menunjukkan keteguhan berperilaku tertib dan patuh pada berbagai peraturan dan norma yang berlaku baik ketika berada di sekolah maupun di dalam lingkungan masyarakat. Disiplin yang diterapkan seseorang akan berdampak baik dalam diri seseorang karena dapat menjadikan diri orang tersebut berguna untuk diri sendiri dan orang lain.

Menipisnya atau bahkan menghilangnya sikap disiplin pada peserta didik merupakan masalah serius yang dihadapi oleh dunia pendidikan karena dapat mengakibatkan terhambatnya proses pendidikan sehingga menghambat tercapainya cita-cita pendidikan.

Kegiatan formal di sekolah tidak lepas dari tata tertib yang mengatur perilaku semua pihak pada lingkungan sekolah, salah satunya untuk peserta didik. Tata tertib yang berlaku berkaitan erat dengan perilaku disiplin yang masih menjadi permasalahan di sekolah. Tujuan utama tata tertib adalah melatih disiplin dan menanamkan disiplin moral dalam diri individu yang akan membentuk pola perilaku, sehingga tata tertib menjadi sebuah kontrol perilaku agar sesuai dengan peraturan.

Paul dalam Budi Wahyono menjelaskan bahwa pengertian disiplin adalah seni menanamkan serangkaian nilai dalam diri yang akan mengajarkan tentang batasan-batasan dari sebuah perilaku yang tepat dan tidak tepat. Paparan tersebut dapat dimaknai bahwa disiplin bukan 
memerintah tetapi mengajarkan sehingga menjadi suatu kebiasaan yang baik. Disiplin juga diartikan sebagai tindakan yang sesuai dengan prosedur yang telah ditetapkan, artinya perilaku yang mengikuti aturanaturan, dan adanya konsekuensi apabila terjadi pelanggaran atau penyimpangan (Budi Wahyono, 2012).

Disiplin akan menanamkan sebuah rasa tanggungjawab dan pertimbangan, sehingga peserta didik mampu membuat keputusan dengan penuh pertimbangan berkaitan dengan perilaku yang dilakukan. Disiplin adalah perilaku taat pada peraturan yang telah ditetapkan, dilakukan dengan penuh kesadaran sehingga membentuk rasa tanggungjawab dalam berperilaku. Individu yang memiliki kedisiplinan yang tinggi akan mampu mengendalikan dorongan dalam dirinya serta mampu menjalani kehidupan dengan control internal dan eksternal.

Disiplin adalah pelatihan pola pikir dan karakter, sehingga disiplin sebagai upaya pengembangan dan pengendalian pola pikir dan karakter dengan tujuan untuk menciptakan kepatuhan dan ketaatan kepada perilaku tertib dan taat. Sri Ratna dan Sri Murtini dalam Budi Wahyono menjelaskan dua tujuan dalam pelaksanaan perilaku disiplin, yaitu: (1) tindakan disiplin memastikan perilaku yang konsisten dengan aturan, (2) mempertahankan rasa hormat dan saling percaya. Perilaku disiplin juga berkaitan erat dengan perilaku tidak disiplin yang akan mendasari perilaku tidak disiplin terhadap tata tertib sekolah. Tidak disiplin adalah perilaku yang melanggar tata tertib atau aturan yang berlaku. Tidak disiplin adalah perilaku yang tidak mentaati ketentuan yang berlaku (Budi Wahyono, 2012).

Perilaku tidak disiplin dapat diartikan sebagai perilaku yang tidak taat kepada aturan, dan norma yang berlaku di lingkungan. Perilaku tidak disiplin merupakan perilaku tidak bertanggungjawab terhadap diri sendiri atas tindakan yang dilakukan. Perilaku disiplin berkaitan dengan tata tertib sekolah atau peraturan sebagai batasan norma yang telah ditetapkan dan disepakati. Peserta didik yang menaati tata tertib berarti telah 
menunjukkan perilaku disiplin. Tata Tertib Peserta Didik adalah segala ketentuan yang ditetapkan oleh sekolah untuk ditaati dan dilaksanakan oleh peserta didik yang bertujuan agar kegiatan belajar mengajar dapat berlangsung efektif (Syaiful Bahri Djamarah, 2000).

Paparan di atas, memberi kesimpulan bahwa perilaku disiplin tata tertib di sekolah adalah perilaku yang sesuai dengan peraturan dan norma yang ditetapkan oleh pihak sekolah untuk membentuk rasa tanggungjawab dalam berperilaku di lingkungan sekolah. Salah satu faktor yang mendukung dalam pembentukan dan peningkatan sikap kedisiplinan peserta didik adalah peran dari guru pendidikan agama Islam.

Guru pendidikan agama Islam (PAI) merupakan guru yang mengajarkan moral kepada siswa, agar kelak menjadi warga masyarakat yang baik, yang beriman dan bertakwa kepada Tuhan YME. Peran guru PAl sangat penting dalam meningkatkan moral siswa yang sekarang ini banyak merosot dalam kehidupan sehari-hari, baik itu di lingkungan sekolah, keluarga maupun masyarakat. Guru PAI dituntut untuk menjadi teladan sesuai bidang studi yang diajarkannya, yaitu memberikan pendidikan agama sesuai dengan ajaran Islam. Pendidikan agama Islam diberikan dengan tujuan agar anak didik dapat menjadi manusia yang berintelektual serta beriman dan berketakwaan yang baik sesuai ajaran Islam (Zakiyah Daradjat, 1995).

Dari studi awal yang dilakukan peneliti di SMP Persiapan Tomi-Tomi Kecamatan Waesala Kabupaten Seram Bagian Barat, dapat dijelaskan bahwa peserta didik kelas VII belum disiplin dalam melakukan berbagai kegiatannya di sekolah maupun di luar sekolah. Di sekolah peserta didik kelas VII masih terlihat sering datang terlambat, terlambat mengumpulkan tugas (PR), tidak disiplin belajar ketika di ruang kelas. Sedangkan ketika di luar sekolah atau berada di lingkungan keluarga dan masyarakat, peserta didik kelas VII tidak disiplin dalam melakukan tugas PR atau belajar di rumah, serta tidak disiplin melaksanakan shalat lima waktu. Nabi Saw yang memerintahkan untuk mendirikan shalat mulai umur tujuh tahun, 
supaya anak terbiasa sejak kecil mendirikan shalat, yang apabila kewajibannya sudah sampai, di kala dia mempunyai kewajiban shalat setelah akil baligh, si anak sudah terbiasa melakukan shalat. Rasulullah Saw bersabda:

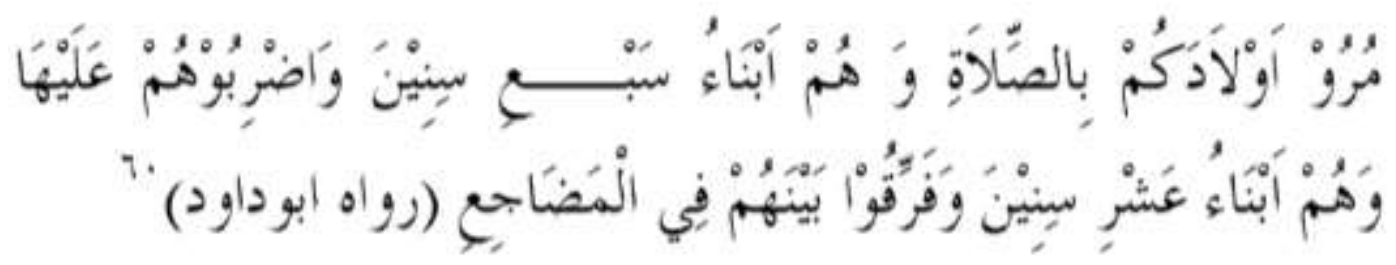

Artinya:

"Suruhlah anak-anakmu mengerjakan shalat, sedang mereka berumur tujuh tahun. Dan pukullah mereka karena meninggalkannya, sedang mereka berumur sepuluh tahun dan pisahlah di antara mereka itu dari tempat tidurnya". (H.R. Abu Dawud) (Bey Arifin, dkk, 1992).

Melihat kondisi peserta didik kelas VII SMP Persiapan Tomi-Tomi yang belum disiplin (baik di sekolah maupun di rumah), maka guru PAI di sekolah tersebut selalu berupaya agar peserta didik kelas VII lebih disiplin, baik disiplin belajar maupun disiplin melaksanakan shalat lima waktu. Guru PAI di SMP Persiapan Tomi-Tomi menyadari bahwa menjadi guru yang bermutu dan profesional harus mampu melaksanakan peranannya dengan baik. Sardiman, A. M menyatakan bahwa peranan guru antara lain: sebagai pendidik, pengajar, dan pembimbing/teladan (Sardiman, 2001). Dari observasi awal terlibat pula bahwa, upaya-upaya yang dilakukan guru PAI di SMP Persiapan Tomi-Tomi antara lain mengamati (mengontrol) aktivitas peserta didik baik pada jam sekolah maupun di luar jam sekolah, memberikan nasihat, menegur, memberikan bimbingan dan memberikan hukuman, serta upaya-upaya lainnya. Namun hingga saat ini belum penelitian yang secara spesifik mengkaji tentang peranan guru PAI di SMP Persiapan Tomi-Tomi dalam meningkatkan kedisiplinan peserta didik.

Dari paparan di atas, maka penulis berkeinginan melakukan sebuah penelitian dengan judul "Peran Guru PAI dalam Meningkatkan 
Kedisiplinan Peserta Didik di Kelas VII SMP Persiapan Tomi-Tomi Kecamatan Waesala Kabupaten Seram Bagian Barat”.

Tujuan penelitian ini adalah untuk mengetahui peran guru PAI dalam meningkatkan kedisiplinan peserta didik di Kelas VII SMP Persiapan Tomi-Tomi Kecamatan Waesala Kabupaten Seram Bagian Barat dan untuk mengetahui faktor pendukung dan faktor penghambat perannya.

\section{METODE}

Jenis penelitian yang dilakukan adalah penelitian partisipatoris, yakni peneliti langsung berada di lokasi penelitian untuk melakukan interview langsung dengan informan untuk memperoleh informasi tentang masalah yang diteliti. Sementara pendekatan yang digunakan adalah pendekatan deskriptif kualitatif, yaitu berupa kata-kata tertulis atau lisan dari orang-orang dan perilaku yang dapat diamati, menggambarkan suatu fakta, gejala atau fenomena yang ditemukan di lapangan atau yang dipelajari (Margono, 2009). Prosedur pengumpulan data yang digunakan dalam penelitian ini adalah pengamatan lapangan (observasi), wawancara (interview) dan dokumentasi. Analisis data dilakukan secara kualitatif dengan mengacu pada model Milles dan Huberman meliputi Reduksi Data (Data Reducation), Penyajian Data (Data Display) dan Penarikan Kesimpulan (Verification).

\section{HASIL DAN PEMBAHASAN}

\section{A. Peran Guru PAI Dalam Meningkatkan Kedisiplinan Peserta Didik di Kelas VII SMP Persiapan Tomi-Tomi.}

Dalam penelitian ini, peneliti mengkaji tentang peran guru mata pelajaran PAI dalam meningkatkan kedisiplinan peserta didik kelas VII SMP Persiapan Tomi-Tomi Kecamatan Waesala Kabupaten Seram Bagian Barat. Dan dari hasil wawancara bersama kepala sekolah terungkap bahwa kedisiplinan peserta didik di SMP Persiapan Tomi-Tomi secara keseluruhan dan khususnya untuk kelas VII dianggap belum baik atau kurang disiplin. Hal ini karena peserta didik masih sering datang 
terlambat ke sekolah, terlambat menyelesaikan tugas rumah atau PR, tidak disiplin mengerjakan shalat dan mereka juga kurang disiplin belajar baik di sekolah maupun di rumah (Wawancara. Imran Wabula, 2018).

Kepala sekolah juga menambahkan bahwa kondisi kedisiplinan peserta didik yang belum begitu baik saat ini menjadi prioritas bagi pihak sekolah, hanya saja sampai upaya yang dilakukan belum mencapai hasil yang maksimal. Pihaknya akan terus berupaya agar peserta didik di sekolah tersebut ke depannya lebih disiplin, karena menurutnya jika peserta didik disiplin maka mereka akan menjadi orang-orang yang sukses.

Mengenai kedisiplinan peserta didik Kelas VII SMP Persiapan TomiTomi, maka Ny. Aspiah Idris selaku guru mata pelajaran PAI mengungkapkan penyataan serupa dengan kepala sekolah, bahwa menurutnya kedisiplinan merupakan suatu hal yang sangat penting, terutama oleh peserta didik, karena kedisiplinan itu akan membawa mereka menjadi orang-orang yang sukses, baik di sekolah ini maupun ketika keluar dari sekolah ini. Dan sampai saat ini ia merasa kedisiplinan peserta didik di sekolah tersebut belum baik, karena banyak peserta didik yang masih sering datang terlambat, termasuk peserta didik kelas VII (Wawancara. Aspiah Idris, 2018).

Peran guru PAI dalam meningkatkan kedisiplinan peserta didik kelas VII di SMP Persiapan Tomi-Tomi, menurut Imran Wabula selaku kepala sekolah bahwa guru PAI sudah cukup berperan dalam hal peningkatan kedisiplinan peserta didik di sekolah tersebut, karena selain memperhatikan kegiatan peserta didik di sekolah ia juga mengontrol jam belajar dan shalat para peserta didik sampai di rumah-rumah mereka. Dalam ruang kelas juga ia selalu memberikan nasihat tentang disiplin. Menegur dan memberikan hukuman bagi peserta didik yang terlambat datang ke sekolah, bahkan beliau marah-marah kalau peserta didik tersebut sudah berulangkali datang terlambat. Guru PAI juga merupakan 
salah satu guru yang paling disiplin di sekolah tersebut (Wawancara. Imran Wabula, 2018).

Kepala sekolah juga menyampaikan bahwa peranan guru PAI selama ini dalam meningkatkan kedisiplinan peserta didik kelas VII maupun peserta didik lainnya sudah cukup baik dan sudah efektif, hanya saja butuh kesabaran, ketabahan dan keikhlasan dalam melakukan semua upaya tersebut, sebab semua upaya tersebut butuh proses, mendisiplinkan peserta didik itu cukup sulit, tidak semudah membalikkan telapak tangan. Apalagi peserta didik kelas VII, mereka itu perlu secara terus menerus diberikan nasihat dan masukan agar selalu disiplin, karena hari ini diberi tahu bahkan diberikan hukuman, besoknya mereka sudah mengulanginya lagi. la juga menyadari bahwa tugas mendisiplinkan peserta didik ini bukan tugas orang per orang atau tugas pribadi, tetapi ini tanggung jawab semua pihak, baik kepala sekolah, guru, orang tua dan peserta didik itu sendiri, jadi semuanya harus bersinergi, harus bekerja sama agar SMP Persiapan Tomi-Tomi ke depannya lebih baik lagi (Wawancara. Imran Wabula, 2018).

Pernyataan kepala sekolah di atas sejalan dengan pendapat Soegeng Prijodarminto, dalam bukunya "Disiplin Kiat Menuju Sukses" menjelaskan bahwa disiplin didefinisikan sebagai suatu kondisi yang tercipta dan terbentuk melalui proses dari serangkaian perilaku yang menunjukkan ketaatan, kepatuhan, keteraturan dan, atau ketertiban. Nilainilai tersebut telah menjadi bagian perilaku dalam kehidupannya. Perilaku itu tercipta melalui proses binaan melalui keluarga, pendidikan dan pengalaman. Sikap dan perilaku demikian ini tercipta melalui proses binaan melalui keluarga, pendidikan dan pengalaman atau pengenalan keteladanan dari lingkungannya. Disiplin akan membuat dirinya tahu dan membedakan hal-hal apa yang seharusnya dilakukan, yang wajib dilakukan, yang boleh dilakukan, yang tidak sepatutnya dilakukan (karena merupakan hal-hal yang dilarang) (Muhaimin, 2002). 
Sementara menurut guru mata pelajaran PAI pada SMP Persiapan Tomi-Tomi bahwa upaya yang ia lakukan dalam rangka meningkatkan kedisiplinan peserta didik adalah harus datang tepat waktu di sekolah sehingga menjadi teladan yang baik kepada peserta didik dalam hal disiplin. Menurutnya jika seorang guru memberikan nasihat kepada peserta didik maka guru tersebut sudah harus melakukannya terlebih dahulu, sehingga hal itu menjadi contoh bagi anak didiknya. Guru PAI juga memberikan nasihat kepada peserta didik tentang kedisiplinan, baik disiplin sekolah maupun disiplin ketika di rumah, disiplin dalam segala hal, disiplin belajar, disiplin datang ke sekolah, disiplin mengerjakan shalat, mengerjakan PR dan lain-lain. la juga memberikan teguran dan memberikan hukuman kepada peserta didik jika mengulangi kesalahannya. Terkadang ia memarahi peserta didik yang sering (berulang-ulang) datang terlambat. Bahkan agar peserta didik itu disiplin, ia harus mengontrol kegiatan peserta didik di sekolah maupun di rumah (Aspiah Idris, 2018).

Kemudian berdasarkan observasi terhadap kegiatan guru PAI dan peserta didik di sekolah tersebut, dapat dijelaskan bahwa jadwal apel pagi bagi peserta didik adalah pada pukul 07.10 WIT, namun masih terlihat banyak peserta didik termasuk kelas VII yang datang terlambat dan diberikan hukuman berupa sit up atau push up, bahkan yang sudah sangat terlambat tidak mau mengikuti apel pagi dan berupaya menyusup melalui jendela sekolah, padahal pada papan Tata Tertib Sekolah telah ditegaskan bahwa peserta didik dilarang terlambat dan harus hadir 15 menit sebelum apel. Tidak hanya peserta didik, guru-guru sebagian juga datang terlambat. Hanya guru yang bertugas piket yang datang tepat waktu. Sementara guru PAI, yakni Ny. Aspiah Idris hadir 7 menit lebih awal dari jadwal yang ditentukan oleh sekolah. Bahkan kepala sekolah datang terlambat, yakni pukul 10.00 WIT.

Berdasarkan penjelasan hasil wawancara dan fakta lapangan selama melakukan observasi, peneliti kemudian menyimpulkan bahwa 
peran seorang guru Pendidikan Agama Islam (PAI) dalam meningkatkan kedisiplinan peserta didik di Kelas VII SMP Persiapan Tomi-Tomi Kecamatan Waesala Kabupaten Seram Bagian Barat antara lain: a) memberikan contoh (teladan) kedisiplinan bagi peserta didik yakni dengan datang ke sekolah tepat waktu; memberikan nasihat kepada peserta didik tentang kedisiplinan; b) menegur dan memberikan hukuman kepada peserta didik yang datang terlambat; c) memarahi peserta didik yang sering (berulang-ulang) datang terlambat; dan d) mengontrol kegiatan peserta didik di sekolah maupun di rumah. Dengan demikian, guru PAI dalam hal ini lebih berperan sebagai seorang pendidik dan pemberi teladan daripada hanya sekedar menjadi seorang pengajar.

Dari penjelasan-penjelasan di atas, dapat pertegas bahwa timbulnya sikap kedisiplinan pada peserta didik bukan merupakan peristiwa yang terjadi seketika dan mudah. Kedisiplinan pada seseorang tidak dapat tumbuh tanpa intervensi dari pendidikan, dan itupun dilakukan secara bertahap, sedikit demi sedikit. Namun kebiasaan ini harus ditanamkan oleh guru dan orang tua di dalam lingkungan sekolah maupun lingkungan keluarga sehingga akan menjadi modal besar bagi kesuksesan peserta didik di masa yang akan datang.

\section{B. Faktor Pendukung dan Faktor Penghambat Peran Guru PAI Dalam Meningkatkan Kedisiplinan Peserta Didik di Kelas VII SMP Persiapan Tomi-Tomi.}

\section{Faktor Pendukung}

Dalam upaya meningkatkan kedisiplinan peserta didik, terdapat faktor yang mendukung hal tersebut. Menurut Ny. Aspiah Idris selaku guru PAl bahwa faktor yang mendukung dalam hal kedisiplinan peserta didik adalah penerapan aturan dan tata tertib di sekolah ini yang saya rasa sudah semakin baik. Dan yang berikut adalah peran kepala sekolah yang juga cukup tegas terhadap masalah kedisiplinan baik itu bagi guru maupun bagi peserta didik (Wawancara. Aspiah Idris, 2018). 
Dengan demikian, dapat diketahui bahwa faktor yang mendukung peran guru PAI dalam meningkatkan kedisiplinan peserta didik di Kelas VII SMP Persiapan Tomi-Tomi Kecamatan Waesala Kabupaten Seram Bagian Barat, antara lain adalah : 1) penerapan aturan dan tata tertib sekolah yang semakin baik; 2) peran kepala sekolah yang cukup tegas terhadap masalah kedisiplinan baik guru maupun peserta didik.

\section{Faktor Penghambat dan Cara Mengatasinya}

Sejalan dengan apa yang sudah diungkapkan mengenai peran guru PAI dalam meningkatkan kedisiplinan peserta didik, maka setiap guru PAI dihadapkan pada tantangan untuk melaksanakan pengembangan kepribadian dan kedisiplinan peserta didik tersebut secara terarah, terencana dan berkesinambungan untuk meningkatkan kualitas pendidikan yang berorientasi pada mutu untuk secara terus menerus memperbaiki kualitas kepribadian dan kedisiplinan peserta didik.

Menurut guru PAI di SMP Persiapan Tomi-Tomi, Ny. Aspiah Idris, bahwa faktor penghambat perannya, baik sebagai pendidik, pengajar maupun sebagai pemberi teladan, dalam upaya meningkatkan kedisiplinan peserta didik kelas VII dan peserta didik lainnya pada lembaga pendidikan tersebut, yakni kurang adanya kerja sama antar sesama guru hal membentuk kepribadian berupa kedisiplinan peserta didik yang lebih baik. Guru-guru juga masih banyak yang memberikan tugas secara individu daripada tugas kelompok, sehingga peserta didik mengerjakan pekerjaannya sendiri dan sering terlambat dikumpulkan, karena terkadang peserta didik butuh kerja sama dan semangat dari teman-temannya dalam menyelesaikan pekerjaan rumah (PR). Selain itu, terdapat pula faktor kurangnya kesadaran peserta didik untuk menjadi orang yang hidup disiplin, dan juga kurangnya kesadaran orang tua dalam memperhatikan kedisiplinan peserta didik ketika di rumah serta guru PAI sering mendapat kritik dan saran yang tidak membangun dari masyarakat ataupun orang tua peserta didik (Aspiah Idris, 2018). 
Menurut Imran Wabula sebagai kepala sekolah bahwa mengenai faktor pendukung dalam meningkatkan kedisiplinan peserta didik kelas VII di SMP Persiapan Tomi-Tomi diantaranya adalah berasal dari para guru di sekolah, kemudian pihak orang tua dan oleh peserta didik itu sendiri. Di sekolah misalnya tidak semua guru mampu memberikan teladan kedisiplinan bagi peserta didik, kurang kerja sama antara guru-guru. Sementara dari diri peserta didik, terlihat bahwa kesadaran peserta didik untuk menjadi orang yang disiplin juga masih belum ada. Dan dari pihak orang tua disebutkan bahwa banyak orang tua yang belum membantu para guru dalam mendisiplinkan anak-anak mereka, orang tua belum begitu memperhatikan kedisiplinan anak di rumah (Wawancara. Imran Wabula, 2018).

Berdasarkan penjelasan-penjelasan di atas, maka dapat disimpulkan bahwa faktor yang menghambat peran guru PAI dalam meningkatkan kedisiplinan peserta didik di Kelas VII SMP Persiapan Tomi-Tomi Kecamatan Waesala Kabupaten Seram Bagian Barat, antara lain adalah: a) kurang adanya kerja sama antar sesama guru, b) kurangnya kesadaran peserta didik untuk menjadi orang yang disiplin; c) kurangnya kesadaran orang tua dalam memperhatikan kedisiplinan peserta didik ketika di rumah; d) masih banyak guru yang memberikan tugas secara individu daripada tugas kelompok; dan e) guru PAl sering mendapat kritik dan saran yang tidak membangun dari masyarakat ataupun orang tua peserta didik.

\section{KESIMPULAN}

1. Peran guru PAI dalam meningkatkan kedisiplinan peserta didik di Kelas VII SMP Persiapan Tomi-Tomi Kecamatan Waesala Kabupaten Seram Bagian Barat antara lain: memberikan contoh (teladan) kedisiplinan bagi peserta didik yakni dengan datang ke sekolah tepat waktu; memberikan nasihat kepada peserta didik tentang kedisiplinan; menegur dan memberikan hukuman kepada peserta didik yang datang terlambat; memarahi peserta didik yang sering (berulang-ulang) datang 
terlambat; dan mengontrol kegiatan peserta didik di sekolah maupun di rumah. Dengan demikian, guru PAI dalam hal ini lebih berperan sebagai seorang pendidik dan pemberi teladan daripada hanya sekedar menjadi seorang pengajar.

2. Faktor pendukung dan faktor penghambat peran guru PAI dalam meningkatkan kedisiplinan peserta didik di Kelas VII SMP Persiapan Tomi-Tomi Kecamatan Waesala Kabupaten Seram Bagian Barat, antara lain untuk faktor pendukung adalah penerapan aturan dan tata tertib sekolah, peran kepala sekolah yang cukup tegas terhadap masalah kedisiplinan baik guru maupun peserta didik. Sedangkan untuk faktor penghambatnya adalah kurang adanya kerja sama antar sesama guru, kurang kesadaran peserta didik untuk menjadi orang yang disiplin, kurangnya kesadaran orang tua dalam memperhatikan kedisiplinan peserta didik ketika di rumah, masih banyak guru yang memberikan tugas secara individu daripada tugas kelompok, dan guru PAI sering mendapat kritik dan saran yang tidak membangun dari masyarakat ataupun orang tua peserta didik.

\section{UCAPAN TERIMA KASIH}

Penulis menyampaikan terima kasih dan penghormatan yang tulus kepada kedua orang tua tercinta, terima kasih atas segala cinta, kasih sayang, perhatian, motivasi, dukungan, pengorbanan dan untaian doa yang tiada henti untuk kebaikan penulis. Pada kesempatan ini pula, perkenankanlah penulis menyampaikan terima kasih yang tulus kepada:

1. Dr. H. Hasbollah Toisuta, M.Ag selaku Rektor IAIN Ambon, Dr. H. Mohdar Yanlua, MH selaku Wakil Rektor I, Dr. H. Ismail DP. M.Pd selaku Wakil Rektor II, dan Dr. Abdullah Latuapo, M.Pd.I selaku Wakil Rektor III.

2. Dr. Samad Umarella, M.Pd selaku Dekan Fakultas IImu Tarbiyah dan Keguruan, Dr. Patma Sopamena, M.Pd selaku Wakil Dekan I, Ummu Sa'idah, M.Pd.I selaku Wakil Dekan II, dan Dr. Ridhwan Latuapo, M.Pd.I selaku Wakil Dekan III. 
3. Dr. Hj. St Jumaeda, M.Pd.I selaku Ketua Program Studi Pendidikan Agama Islam dan E. M. Dhuhani, S.Hum., M.Pd selaku Sekretaris Jurusan Pendidikan Agama Islam, serta seluruh staf Program Studi Pendidikan Agama Islam.

4. Dr. Adam Latuconsina, M.Si selaku Pembimbing I dan Dr. Muhajir Abdurrahman, M.Pd.I, selaku Pembimbing II yang telah meluangkan waktu membimbing penulis dengan penuh kesabaran dan keikhlasan sehingga penulis dapat menyelesaikan skripsi ini dengan baik.

5. Ainun Diana Lating, M.Si selaku Penguji I dan Nur Khizin, M.Pd.I selaku Penguji II yang telah meluangkan waktu untuk menguji dan terbuka untuk mengarahkan penulis dalam menyelesaikan skripsi ini.

6. Rivalna Riva'i, M.Hum selaku Pimpinan Perpustakaan IAIN Ambon beserta staf yang telah bersedia menyediakan literatur untuk penulis selama menyusun skripsi.

7. Seluruh Dosen dan Pegawai pada Fakultas IImu Tarbiyah dan Keguruan, khususnya Program Studi Pendidikan Agama Islam IAIN Ambon yang telah mendidik serta membimbing penulis hingga akhir studi.

8. Istriku Mahasia, S.Sos.I dan buah hati kami yang selalu bersamaku baik dalam suka maupun duka, yang selalu memberi semangat kepadaku dalam proses studi di IAIN Ambon.

9. Saudara-Saudara Tercinta: Panee, Aljidan, Wa Ube, Masnia dan Wa Finanti yang selalu memberi semangat dan motivasi, serta menjadi sumber inspirasi penulis selama mengenyang pendidikan di IAIN Ambon.

\section{DAFTAR PUSTAKA}

[1] Daradjat, Zakiyah. Pendidikan Islam Dalam Keluarga dan Sekolah. Jakarta: Ruhana, 1995.

[2] Djamarah, Syaiful Bahri. Strategi Belajar Mengajar. Jakarta: Rineka Cipta, 2002. 
[3] Dkk. Bey Arifin. Tarjamah Sunan Abi Daud, Semarang: CV. Asy Syifa, 1992.

[4] ---------. Guru Dan Anak Dalam Interaksi Edukatif. Jakarta: PT Rineka Cipta, 2000.

[5] Gunarso, Singgih D. Psikologi untuk Membimbing. Jakarta : PT. Gunung Mulia, 2000.

[6] Karman, M., Teknik Penulisan Karya Ilmiah: Program Studi Pendidikan Agama Islam Fakultas IImu Tarbiyah dan Keguruan IAIN Ambon. Cet. II: Jakarta: Hilliana Press dan STAIN Ambon. 2013.

[7] Majid, Abdul. Perencanaan Pembelajaran. Bandung: PT Remaja Rosda Karya, 2006.

[8] Margono. Metodologi Penelitian Pendidikan. Cet. VII; Jakarta : PT. Rineka Cipta, 2009.

[9] Muhaimin. Paradigma Pendidikan Islam : Upaya Mengefektifkan Pendidikan Islam Di Sekolah. Bandung: Rosdakarya, 2002.

[10] Wahyono, Budi. Pengertian Kedisiplinan Belajar, 2012, diakses tanggal 06 Januari 2018, http://www.html. 